\title{
ANALISIS BIAYA, PENERIMAAN, PENDAPATAN DAN R/C PADA AGROINDUSTRI SERUNDENG KELAPA (Studi Kasus Pada PT. Dinaya Sambiana Loemintoe Dusun Cikoranji Desa Cimindi Kecamatan Cigugur Kabupaten Pangandaran)
}

\author{
DEDE SAEPUL ANFAL ${ }^{1}$, MUHAMAD NURDIN YUSUF ${ }^{1}$, BUDI SETIA $^{1}$ \\ ${ }^{1}$ Fakultas Pertanian, Universitas Galuh \\ *E-mail: dedesaepula@gmail.com
}

\begin{abstract}
ABSTRAK
Penelitian ini bertujuan untuk mengetahui : 1) Besarnya biaya produksi yang dikeluarkan PT. Dinaya Sambiana Loemintoe per satu kali proses produksi, 2) Besarnya penerimaan yang diterima PT. Dinaya Sambiana Loemintoe per satu kali proses produksi, 3) Besarnya pendapatan yang diterima PT. Dinaya Sambiana Loemintoe per satu kali proses produksi, 4) Besarnya R/C yang didapatkan PT. Dinaya Sambiana Loemintoe per satu kali proses produksi. Penelitian ini dilakukan di Dusun Cikoranji Desa Cimindi Kecamatan Cigugur Kabupaten Pangandaran dengan menggunakan Metode Studi Kasus. Dengan mengambil sampel pada seorang pengusaha agroindustri serundeng kelapa. Hasil penelitian menunjukkan bahwa: 1) Besarnya biaya produksi yang dikeluarkan PT. Dinaya Sambiana Loemintoe per satu kali proses produksi adalah Rp 7.504.763,- 2) Besarnya penerimaan yang diterima PT. Dinaya Sambiana Loemintoe per satu kali proses produksi adalah Rp 14.000.000.- 3) Besarnya pendapatan yang diterima PT. Dinaya Sambiana Loemintoe per satu kali proses produksi adalah Rp 6.495.237,- 4) Besarnya R/C yang didapatkan PT. Dinaya Sambiana Loemintoe per satu kali proses produksi adalah 1,86 .
\end{abstract}

Kata kunci: Biaya, Kelapa, Pendapatan, Penerimaan, R/C

\begin{abstract}
This study aims to determine: 1) The amount of production costs incurred by PT. Dinaya Sambiana Loemintoe per one time production process, 2) The amount of revenue received by PT. Dinaya Sambiana Loemintoe per one time production process, 3) The amount of income received by PT. Dinaya Sambiana Loemintoe per one production process, 4) The amount of $R$ / C obtained by PT. Dinaya Sambiana Loemintoe per one production process. This research was conducted in Cikoranji Hamlet, Cimindi Village, Cigugur District, Pangandaran Regency, using the Case Study Method. By taking a sample of a coconut serundeng agro-industry entrepreneur. The results showed that: 1) The amount of production costs incurred by PT. Dinaya Sambiana Loemintoe per one time production process is Rp. 7,504,763, - 2) The amount of revenue received by PT. Dinaya Sambiana Loemintoe per one time production process is Rp. 14,000,000.- 3) The amount of income received by PT. Dinaya Sambiana Loemintoe per one time production process is $R p$ 6,495,237, - 4) The amount of $R / C$ obtained by PT. Dinaya Sambiana Loemintoe per one time production process is 1.86.
\end{abstract}

Keywords: Coconut, Cost, Income, $R / C$, Revenues

\section{PENDAHULUAN}

Tanaman kelapa memiliki potensi keragaman produk yang tinggi karena semua bagian dari tanaman ini bisa dibisniskan mulai dari akar, batang, bunga, buah dan daunnya bisa mendatangkan rupiah bahkan dollar (Suriawira, 2002).

Tanaman kelapa dikenal sebagai pohon yang mempunyai banyak kegunaan muali dari akar sampai pada ujungnya (daun), dari produk non kuliner/makanan, 
dan juga produk industri sampai produk obat-obatan. Bagi banyak negara di dunia, tanaman ini disebut sebagai pohon kehidupan (Nursuci, 2012).

Kabupaten Pangandaran provinsi Jawa Barat merupakan salah satu kabupaten penghasil kelapa dengan luas total lahan dari 10 kecamatan sebanyak 25.360,38 ha (Dinas Pertanian Kabupaten Pangandaran, 2018).

Data luas tanaman dan produksi tanaman kelapa di Kabupaten Pangandaran. Dapat dilihat pada Tabel 1.

Tabel 1. Luas Tanam, Luas Tanaman Menghasilkan, Produksi dan Produktivitas Tanaman Kelapa di Kabupaten Pangandaran Tahun 2017

\begin{tabular}{rlrrrr}
\hline No & Kecamatan & $\begin{array}{r}\text { Luas Tanaman } \\
\text { Tahun } 2017(\mathrm{ha})\end{array}$ & $\begin{array}{r}\text { Luas Tanaman } \\
\text { (ha) }\end{array}$ & Produksi (ton) & Produktivitas (ton/ha) \\
\hline $\mathbf{1 .}$ & Cigugur & $\mathbf{2 . 1 6 5 , 4 1}$ & $\mathbf{2 . 1 6 4 , 4 1}$ & $\mathbf{2 0 8 , 5 8 6}$ & $\mathbf{9 6 . 3 7}$ \\
2. & Cijulang & $3.834,40$ & $3.834,00$ & 442,396 & 115.39 \\
3. & Cimerak & $4.575,42$ & $5.141,78$ & 453,43 & 0.09 \\
4. & Kalipucang & $4.030,09$ & $4.029,81$ & 451,87 & 0.11 \\
5. & Langkaplancar & 543,7 & 525,7 & 546,9 & 1.04 \\
6. & Mangunjaya & 759,06 & 759,27 & $5,300,00$ & 6.98 \\
7. & Padaherang & $2.322,07$ & $2.323,43$ & 321,98 & 0.14 \\
8. & Pangandaran & $1.783,07$ & $1.783,35$ & 4,144 & 2.32 \\
9. & Parigi & $5.946,22$ & $2.819,10$ & 578,88 & 0.20 \\
10. & Sidamulih & $1.829,64$ & $1.829,64$ & 144,48 & 0.07 \\
\hline & Jumlah & $\mathbf{2 7 . 7 8 9 , 0 8}$ & $\mathbf{2 5 . 3 6 0 , 3 8}$ & $\mathbf{1 2 , 5 9 3 , 0 0}$ & - \\
\hline & Rata-rata & $\mathbf{2 . 7 7 8 , 9 1}$ & $\mathbf{2 . 5 3 6 , 0 4}$ & $\mathbf{1 . 2 5 9 , 3 0}$ & $\mathbf{0 , 4 9}$ \\
\hline
\end{tabular}

Sumber: Dinas Pertanian, Kabupaten Pangandaran, 2018

Tabel 1 menunjukkan bahwa Cigugur merupakan salah satu kecamatan dengan urutan produksi kelapa nomor 8 di Kabupaten Pangandaran. PT. Dinaya Sambiana Loemintoe merupakan satusatunya agroindustri di kecamatan Cigugur yang menggunakan kelapa sebagai bahan baku produksi serundeng kelapa. Tidak ada lagi agroindustri yang memproduksi serundeng kelapa dikarenakan permodalan yang terbatas dan harga sarana produksi yang kurang terjangkau oleh masyarakat.
Dengan demikian agroindustri tersebut mampu memberikan banyak keuntungan dikarenakan dalam pembuatan bahan baku yang digunakan serundeng tersebut adalah kelapa sisa atau tidak memenuhi standar jika di jual keluar kota.

Meskipun sudah menghasilkan keuntungan namun belum teradministrasi secara baik sehingga, tidak bisa mengetahui penambahan nilai dari modal yang diinvestasikan, dalam hal tersebut peneliti merasa tertarik untuk meneliti R/C, 
terutama menghitung pendapatan dari usaha Serundeng Kelapa di PT. Dinaya Sambiana Loemintoe di Dusun Cikoranji Desa Cimindi Kecamatan Cigugur Kabupaten Pangandaran.

\section{METODE PENELITIAN}

\section{Jenis Penelitian}

Metode penelitian pada penelitian ini yang digunakan adalah metode studi kasus. Menurut Arikunto (2006), Studi kasus adalah suatu penelitian secara intensif yang dilakukan dan terperinci, serta mendalam yang terdapat pada suatu organisasi, lembaga atau gejala tertentu, baik berupa subyek penelitian secara individu, kelompok, lembaga maupun masyarakat.

\section{Operasionalisasi Variabel}

Variabel-variabel yang diamati dalam penelitian ini dioperasionalisasikan sebagai berikut:

1) Proses produksi Satu kali pengolahan serundeng kelapa dimulai dari pengupasan kelapa, pemarutan buah kelapa, pengeringan parutan kelapa dan pengemasan dilakukan dalam kurun waktu 1 hari.

2) Biaya total (total cost), yaitu keseluruhan biaya yang dikeluarkan satu kali selama proses produksi dinyatakan dalam satuan rupiah. Biaya total meliputi: a. Biaya tetap (fixed cost), yaitu biaya tidak dipengaruhi oleh besar kecilnya produksi, meliputi:

- PBB, diukur dalam satuan meter persegi $\left(\mathrm{m}^{2}\right)$ per satu kali proses produksi.dan dinilai dalam satuan rupiah

- Biaya penyusutan alat dan bangunan, diukur dalam satuan rupiah per satu kali proses produksi dihitung dengan menggunakan sebagai berikut rumus (Suratiyah, 2006):

$$
\text { Penyusutan alat }=\frac{\text { Nilai Beli }- \text { Nilai Sisa }}{\text { Umur Ekonomis }}
$$

Nilai sisa merupakan nilai pada waktu alat itu sudah tidak bisa digunakan lagi atau dianggap nol.

- Modal Bunga biaya tetap adalah nilai bunga modal dari bunga bank yang dihitung berdasarkan biaya tetap yang berlaku, per satu kali proses produksi dinyatakan dalam satuan rupiah.

b. Biaya variabel (variable cost), yaitu besar kecilnya biaya yang dipengaruhi oleh besar kecilnya produksi, meliputi:

- Biaya bahan baku kelapa, per satu kali proses produksi dihitung dalam satuan kilogram dan dinilai dalam satuan rupiah. 
- Biaya bahan bakar, dihitung dalam satuan liter dan per satu kali proses produksi dinilai menggunakan satuan rupiah.

- Biaya tenaga kerja, dihitung dalam HOK dan per satu kali proses produksi dinilai dengan satuan rupiah.

- Bunga modal biaya variabel adalah nilai bunga modal dari biaya variabel demikian dihitung dengan bunga bank yang berlaku, dinyatakan per proses produksi oleh satuan rupiah satu.

3) Penerimaan (revenue), yaitu hasil perkalian antara harga dengan produksi total. satuan produk atau harga jual, dinilai dalam satuan rupiah dalam satu kali produksi.

4) Pendapatan, yaitu pengurangan hasil antara total penerimaan dengan total biaya selama proses produksi satu kali, dinilai dalam satuan rupiah per satu kali proses produksi.

5) R/C yaitu analisis metode untuk mengetahui laba atau rugi usaha dengan memakai rasio biaya (cost) dan penerimaan (revenue) (Darsono, 2008).

\section{Teknik Pengumpulan Data}

Dalam penelitian ini data yang dikumpulkan terdiri dari data sekunder dan data primer. primer Data diperoleh dari wawancara berdasarkan kuesioner terhadap responden (Pemilik/pengelola agroindustri serundeng kelapa). Data sekunder diperoleh dari lembaga atau instansi yang terkait dan dari berbagai literatur yang dengan penelitian ini berhubungan. Metode data pengumpulan dalam penelitian ini yaitu observasi, dan wawancara langsung menggunakan kuesioner.

\section{Teknik Penarikan Sampel}

Penarikan sampel dalam penelitian ini menggunakan teknik penarikan sampel purposive sampling. Menurut Sugiyono (2006) purposive sampling adalah penentuan sampel dengan teknik pertimbangan tertentu.

PT. Dinaya Sambiana Loemintoe dipilih sebagai sampel dengan pertimbangan perusahaan tersebut merupakan satu-satunya usaha agroindustri serundeng kelapa di Dusun Cikoranji Desa Cimindi Kecamatan Cigugur Kabupaten Pangandaran

\section{Rancangan Analisis Data}

Data yang diperoleh di lapangan kemudian dianalisis sesuai dengan tujuan penelitian, yaitu: meliputi analisis biaya, penerimaan, pendapatan dan R/C agroindustri pengolahan serundeng kelapa. 
a. Biaya Produksi

Menurut M Nafarin (2009), produk (barang) yang berkaitan semua biaya dengan yang diperoleh, dimana didalamnya terdapat unsur biaya produk berupa biaya bahan baku, biaya tenaga kerja langsung, dan biaya overhead pabrik.

Biaya produksi dirumuskan sebagai berikut:

$$
\mathbf{T C}=\mathbf{T F C}+\mathbf{T V C}
$$

Keterangan:

- $\quad \mathrm{TC}=$ Total Cost (Biaya total)

- $\quad$ TFC = Total Fixed Cost (Biaya tetap total)

- $\quad$ TVC = Total Variable Cost (Biaya variabel Total)

b. Penerimaan

Menurut Soekartawi (2010), total penerimaan (Total Revenue) dari suatu usaha dapat diperoleh dari hasil perkalian antara jumlah produk yang didapat (terjual) dengan harga dari produk tersebut. Secara matematis dituliskan dengan rumus:

$$
\mathbf{T R}=\mathbf{Y} \mathbf{x} \mathbf{P y}
$$

Keterangan:

- $\quad \mathrm{TR}=$ Total Revenue $($ Penerimaan Total)

- $\quad \mathrm{Y}=$ Produksi

- $\quad$ Py $=$ Harga Produk

c. Pendapatan (Keuntungan)

Menurut Soekartawi (2010) pendapatan merupakan pengurangan antara penerimaan dengan total biaya. Tingkat pendapatan dari suatu kegiatan agroindustri dapat digunakan rumus:

$\Pi=\mathrm{TR}-\mathrm{TC}$

Keterangan:

- $\Pi=$ Keuntungan

- $\quad \mathrm{TR}=$ Penerimaan total

- $\quad \mathrm{TC}=$ Biaya total

d. $\mathrm{R} / \mathrm{C}$

R/C Agroindustri serundeng kelapa dapat dihitung dengan menggunakan analisis $\mathrm{R} / \mathrm{C}$ dengan rumus Soekartawi (2010):

$$
R / C=\frac{T R}{T C}
$$

Keterangan:

- $\quad \mathrm{R} / \mathrm{C}=$ Revenue Cost Ratio.

- $\quad \mathrm{TR}=$ Penerimaan total $(\mathrm{Rp} / \mathrm{tiap}$ produksi).

- $\quad \mathrm{TC}=$ Biaya total $(\mathrm{Rp} / \mathrm{tiap}$ produksi $)$.

\section{Tempat dan Waktu Penelitian}

Penelitian ini dilaksanakan di Dusun Cikoranji Desa Cimindi Kecamatan Cigugur Kabupaten Pangandaran. Adapun waktu penelitian ini direncanakan dibagi dalam beberapa tahap sebagai berikut:

1) Tahapan survei pendahuluan, penulisan Usulan Penelitian, dan Seminar Usulan Penelitian dilaksanakan pada bulan Januari 2019

2) Tahapan mengumpulkan dan mengolah data dilaksanakan pada bulan Februari 2019. 
3) Tahapan penulisan laporan penelitian data dilaksanakan pada bulan Maret 2019 sampai dengan selesai.

\section{HASIL DAN PEMBAHASAN Identitas Responden}

Responden adalah Bapak

Atha'ullah Dwi Payana, beliau merupakan satu-satunya perajin yang menjalankan agroindustri serundeng kelapa dengan rutin di Dusun Cikoranji Desa Cimindi Kecamatan Cigugur Kabupaten Pangandaran. Berikut merupakan Identitas hasil wawancara bersama responden meliputi:

a. Umur Responden

Responden berusia 47 tahun, artinya berada pada usia produktif dalam menjalankan usaha tersebut.

b. Tingkat Pendididkan Responden Perajin agroindustri serundeng kelapa pada PT Dinaya Sambiana Loemintoe adalah S1 Teknik Manajemen Industri.

c. Tanggungan Keluarga Responden Beliau memiliki tanggungan keluarga berjumlah enam orang terdiri dari satu istri dan lima orang anak

d. Pengalaman Berusaha Responden Pengalaman usaha agroindustri serundeng kelapa telah perajin lakukan selama 15 tahun, hal tersebut merupakan modal utama perajin untuk tetap konsiten menjalankan usahanya.

\section{Keadaan Umum Agroindustri}

\section{Serundeng Kelapa}

\section{Pengadaan Sarana Produksi}

Penyediaan sarana produksi dilakukan sendiri oleh perajin. Kelapa merupakan bahan baku utamanya dibeli dari pengepul senilai Rp 1.500,- per butir. Dikarenakan kelapa yang digunakan adalah kelapa sisa dengan ciri-ciri berukuran kecil dan tidak laku dipasaran. Kelapa yang diolah pada agroindustri serundeng di Desa Cimindi satu kali per proses produksi sebanyak 3.000 butir/ satu kali proses produksinya.

\section{Peralatan Usaha Agroindustri} Serundeng Kelapa

Proses pembuatan serundeng kelapa pada agroindustri ini sudah cukup modern. Adapun peralatan yang digunakan adalah sebagai berikut:

a). Kapak

$\begin{array}{lrcr}\text { Berfungsi untuk } & \text { membelah } & \text { dan } \\ \text { membuang air } & \text { kelapa } & \text { dari } \\ \text { tempurungnya. } & & \end{array}$

b). Mesin Butik

Berfungsi untuk membelah kelapa, seperti halnya kapak hanya saja lebih 
modern dan mampu mempercepat proses pembelahan dan pembuangan tempurung kelapa.

c). Pisau

Berfungsi untuk mengupas kulit ari kelapa dari dagingnya yang kemudian di potong kecil tidak beraturan.

d). Ember

Berfungsi untuk menampung daging kelapa yang telah dikupas.

f). Piber

Berfungsi sebagai bak pencucian daging kelapa

e). Keranjang Plastik

Berfungsi untuk meniriskan daging kelapa dari bak pencucian menuju mesin parut

g). Mesin Parut

Berfungsi untuk menggiling/memarut daging kelapa

h). kontener

Berfungsi sebagai wadah setelah daging kelapa selesai diparut

i). Oven

Berfungsi untuk menurunkan kadar air pada parutan kelapa

j). Exhaust Fan

Berfungsi untuk mensirkulasi udara.

k). Skop Kecil

Digunakan untuk mengaduk rata pada saat pengovenan dan pendinginan serundeng
1). Bak Pendingin

Alat ini sebagai wadah untuk mendinginkan serundeng yang telah di oven

$\mathrm{m})$. Kipas angin

Digunakan secara bersamaan dengan bak pendingin untuk mendinginkan serundeng.

n). Timbangan

Alat ini digunakan untuk menimbang serundeng yang siap dikemas.

\section{Proses Pembuatan Serundeng Kelapa}

Proses pembuatan serundeng kelapa terdiri dari 3 tahap, yaitu:

1) Proses mengupasan dan mencuci

a. Memilih kelapa yang cukup tua untuk dijadikan bahan baku, kemudian daging kelapa dipisahkan dari tempurung.

b. Daging kelapa yang sudah dikupas dari tempurung, kemudian dikupas kulit ari yang berwarna coklat. Ini bertujuan untuk membersihkan daging kelapa sehingga akan didapat hasil gilingan yang putih dan bersih.

c. Kemudian hasil kupasan daging kelapa dicuci bersih menggunakan air. 
2) Proses Pemarutan

Kelapa yang sudah dicuci bersih kemudian diparut menggunakan mesin parut.

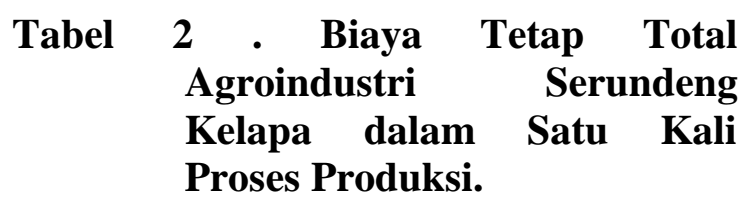

3) Proses Pengeringan

a. Hasil gilingan kelapa kemudian dimasukan ke ruangan khusus untuk dilakukan pengeringan.

b. Waktu yang dibutuhkan selama proses pengeringan ialah kurang lebih 2 jam hingga kelapa parut yang tadinya basah menjadi kering.

c. Setelah kering, kemudian serundeng kelapa selama 1 jam dibiarkan hingga dingin.

2) Proses Pengemasan

Setelah dingin serundeng kelapa siap dikemas menggunakan kantong plastik kapasitas $25 \mathrm{~kg}$, dan tepung kelapa siap dikirim.

\begin{tabular}{clr}
\hline No & Biaya Tetap & $\begin{array}{r}\text { Besarnya } \\
\text { Biaya (Rp) }\end{array}$ \\
\hline 1 & PBB & $4.167,-$ \\
2 & Penyusutan Alat & $128.995,-$ \\
3 & Bunga Modal & $53,-$ \\
& & $\mathbf{1 3 3 . 2 1 5 , -}$ \\
\hline
\end{tabular}

\section{Biaya Variabel}

Adapun biaya variabel yang dihitung dalam penelitian ini meliputi biaya sarana produksi, tenaga kerja dan bunga modal variabel. Total biaya variabel yang dikeluarkan untuk sekali produksi adalah sebesar:

\section{Tabel 3. Biaya Variabel Total Agroindustri Serundeng Kelapa dalam Satu Kali Proses Produksi}

\begin{tabular}{clc}
\hline No & Biaya Variabel & $\begin{array}{c}\text { Besarnya } \\
\text { Biaya } \\
(\mathbf{R p})\end{array}$ \\
\hline 1 & Sarana Produksi & $5.088 .600,-$ \\
2 & Tenaga Kerja & $2.280 .000,-$ \\
3 & Bunga Modal & $2.947,-$ \\
\hline & Jumlah & $\mathbf{7 . 3 7 1 . 5 4 8 , -}$ \\
\hline
\end{tabular}

\section{Biaya Total \\ Biaya total merupakan penjumlahan antara biaya tetap total dengan biaya variabel total. Untuk lebih jelasnya dapat dilihat tabel dibawah ini.}


Tabel 4. Biaya Total Agroindustri Serundeng Kelapa dalam satu Kali Proses Produksi.

\begin{tabular}{rlc}
\hline No & \multicolumn{1}{c}{ Biaya } & Jumlah (Rp) \\
\hline 1 & Biaya Tetap & $133.215,-$ \\
2 & Biaya Variabel & $7.371 .548,-$ \\
\hline & Jumlah & $\mathbf{7 . 5 0 4 . 7 6 3 , -}$ \\
\hline
\end{tabular}

Analisis Penerimaan Agroindustri

\section{Serundeng Kelapa}

Penerimaan adalah perkalian antara jumlah produksi dengan harga jual produk. Harga jual serundeng kelapa yang diperoleh pengelola agroindustri adalah sebesar Rp 20.00.-/kg. Sedangkan produksi serundeng kelapa dalam sekali proses produksi adalah sebesar $700 \mathrm{~kg}$ tepung kelapa. Jadi penerimaan yang diperoleh adalah sebesar Rp 14.000.000.-

\section{Analisis Pendapatan Agroindustri Serundeng Kelapa}

Pendapatan atau keuntungan adalah selisih antara penerimaan dengan biaya total. Total biaya yang dikeluarkan adalah sebesar Rp 7.504.763,- dan total penerimaan adalah sebesar $\mathrm{Rp}$ 14.000.000.- sehingga didapat keuntungan agroindustri pengolahan tepung kelapa adalah sebesar Rp 6.495.237,-

\section{Analisis R/C Agroindustri Serundreng Kelapa}

$\mathrm{R} / \mathrm{C}$ adalah perbandingan antara penerimaan dengan biaya. Jadi penerimaan yang diterima oleh agroindustri serundeng kelapa dalam sekali proses produksi adalah Rp 14.000.000,- dan biaya yang dikeluarkan adalah sebesar Rp 7.504.763,Sehingga didapat R/C pada agroindustri pengolahan serundeng kelapa adalah sebesar 1,86 Artinya setiap biaya yang dikeluarkan $\mathrm{Rp} 1$ akan diperoleh penerimaan sebesar $\operatorname{Rp} 1,86$ dan pendapatan sebesar Rp 0,86 Oleh karena itu agroindustri serundeng kelapa menguntungkan dan layak untuk diusahakan.

\section{KESIMPULAN DAN SARAN}

\section{Kesimpulan}

Berdasarkan penelitian hasil dan pembahasan mampu diambil kesimpulan sebagai berikut:

1) Besarnya biaya produksi yang dikeluarkan PT. Dinaya Sambiana Loemintoe pada pembuatan serundeng kelapa per satu kali proses produksi adalah $\mathrm{Rp}$ 7.504.763,-

2) Besarnya penerimaan yang diterima PT. Dinaya Sambiana Loemintoe pada pembuatan serundeng kelapa per satu 
kali proses produksi adalah $\mathrm{Rp}$ 14.000.000.-

3) Besarnya pendapatan yang diterima PT. Dinaya Sambiana Loemintoe pada pembuatan serundeng kelapa per satu kali proses produksi adalah $\mathrm{Rp}$ 6.495.237,-

4) Besarnya R/C yang didapatkan PT. Dinaya Sambiana Loemintoe pada pembuatan serundeng kelapa per satu kali proses produksi adalah 1,86.

\section{Saran}

Berdasarkan kesimpulan penelitian, maka diajukan saran sebagai berikut :

1) Perajin hendaknya tetap melakukan produksi serundeng kelapa karena usaha tersebut memberikan keuntungan.

2) Harus dilakukan pencatatan perusahaan baik itu pencatatan biaya, penjualan, penerimaan dan pendapatan.
3) Perlu peningkatan skala produksi sehingga akan terjadi peningkatan pendapatan bagi pengelola perusahaan.

\section{DAFTAR PUSTAKA}

Arikunto, S. 2006. Metode Penelitian Kualitatif. Jakarta: Bumi Aksara

Darsono, 2008. Metodologi Riset Agribisnis Buku II Metode Analisis Data. Progam Studi Magister Manajemen Agribisnis Progam Pascasarjana UPN. Veteran. Surabaya

Dinas Pertanian, 2018. Luas Tanaman, Produksi, dan Produktivitas Tanaman Kelapa Dalam Tahun 2017. Kabupaten Pangandaran.

M. Nafarin. 2009. Penganggaran Perusahaan. Penerbit Salemba4. Jakarta.

Nursuci, S. 2012. Teknologi Budidaya Tanaman Kelapa. CV. Amaliah Book. Bandung.

Soekartawi. 2010. Agribisnis: Teori dan Aplikasinya. Jakarta : PT Raja .

Sugiono, D. 2006. Statistika Untuk Penelitian. CV. Alfabeta. Bandung.Grafindo Persada. 238 hal. Suratiyah. 2006. Ilmu Usaha Tani. Penebar Swadaya: Depok. 